\title{
SERBEST ÇALIŞAN MUHASEBE MESLEK MENSUPLARININ YAŞAM DOYUM
} DÜZEYLERI

\author{
iffet KESIMLi ${ }^{1}$, Bahar DOĞRAMACI YALÇIN ${ }^{2}$, Bülent KILIÇ ${ }^{3}$
}

Öz

Bu çalışmada, bireyin yaşamındaki en önemli hedeflerinden biri olan yaşam doyumuna etki eden faktörler incelenmiştir. Gerçekleşen durumun beklentilerle kıyaslanmasıyla ortaya çıkan sonucu gösteren yaşam doyumuna etki eden birçok faktör bulunmaktadır. Çalışma 78 muhasebe meslek mensubu üzerinde yapılmıştır. illk olarak, SM, SMMM ve YMM'lerin yaşam doyumu düzeyleri ile meslekte geçirdikleri süreler, bakmakla yükümlü oldukları kişi sayıları ve yaşları arasında herhangi bir ilişki olup olmadığı incelenmiştir. Ayrıca, bağımsız örneklem t-testi ile çalışanların cinsiyetlerine, medenî durumlarına ve mesleği isteyerek seçip seçmemelerine göre yaşam doyumu düzeylerinde istatistiksel olarak anlamlı bir farklılık olup olmadığı araştırılmıştır. Yalnızca mesleği isteyerek seçip seçmemelerine göre yaşam doyumu düzeylerinde istatistiksel olarak anlamlı bir farklılığa rastlanmıştır. Literatür araştırması, herhangi başka bir olguyla karşılaştırılmaksızın yalnızca yaşam doyumu üzerine yapılan çalışmaların çoğunlukla lise ve üniversite öğrencileri üzerinde yapıldığını ortaya koymuştur. Kalan diğer çalışmaların da muhasebe meslek mensupları üzerinde yapılanların sayısı yeterli değildir. Bu durum çalışmanın literatüre ilave katkısını ortaya koymaktadır.

Anahtar Kelimeler: Yaşam Doyumu, Mutluluk, Muhasebe, Serbest Meslek Mensupları, Türkiye JEL Sinıflandırmasi: J28, M41, M49

\section{SELF-EMPLOYED ACCOUNTANTS' LIFE SATISFACTION LEVELS}

\begin{abstract}
Factors influencing the life satisfaction, which is one of the most important objectives in humans' lives, are examined in this study. There are many factors influencing the life satisfaction that is the comparison of the actual situation against the expectations of the person. The study is conducted with 78 self-employed accountants. Initially, accountants', CPAs' and Sworn-in CPAs' life satisfaction levels are compared to their tenure in the profession, the number of dependant persons they are obliged to look at, and their ages. Secondly with the help of independent sample t-test, the life satisfaction levels of self-employed accountants are analyzed against their gender, marital status, and whether they chose their profession willingly or not. There was only a statistically significant difference between the informed choice of the profession and the levels of life satisfaction. Literature surveys reveals that life satisfaction research, being not compared to any other fact, mostly involves high school and college students. The research on accounting professionals is not satisfactory in numbers. This shows the incremental contribution of this research to the literature.
\end{abstract}

Keywords: Life Satisfaction, Happiness, Accounting, Self-employed Accountants, Turkey

JEL Classification: J28, M41, M49

\footnotetext{
${ }^{1}$ Dr. Öğr. Üyesi, Lüleburgaz Meslek Yüksekokulu, ifkesimli@gmail.com, https://orcid.org/0000-0002-2082-5515

${ }^{2}$ Öğr. Gör., Lüleburgaz Meslek Yüksekokulu, bahardogramaciyalcin@klu.edu.tr, https://orcid.org/0000-0002-9463-6231

${ }^{3}$ Öğr. Gör., Lüleburgaz Meslek Yüksekokulu, bulent.kilic@klu.edu.tr, https://orcid.org/0000-0002-1554-1761
} 


\section{Giriş}

Yüzyıllar boyunca insanoğlunun ilgi odağı olmuş konulardan biri olan yaşam doyumu, bir insanın beklentileri, yani ne istediği ile elinde bulunanların, yani neye sahip olduğu ile karşılaştırılmasıyla elde edilen durum ya da sonuçtur. Yaşam doyumu ifadesiyle yalnızca belirli bir duruma ilişkin doyum değil, genel olarak tüm yaşantı açısından doyum anlaşılmaktadır (Özer ve Özsoy Karabulut, 2003: 72). Her ne kadar bazı çalışmalarda yaşam doyumu ve mutluluk aynı anlamda kullanılmış olsa da, sosyal psikologlar tanımlanması güç ve farklı anlamlara gelen ve günlük yaşamda oldukça sık kullanılan mutluluk kavramı yerine yaşam doyumu veya öznel iyi oluş kavramlarını kullanmaktadır (Özdevecioğlu ve Aktaş, 2007: 7-8).

Hizmet sektörü çalışanlarının meslekî etkililiği, yani kaynakları en iyi şekilde değerlendirerek mümkün olan en iyi sonucu almaları çok sayıda unsurdan etkilendiği gibi, yaşam doyumundan da etkilenmektedir. İnsan yaşamı, iş ve iş dışı yaşantının bütününden oluşur. Bunlardan birinde kendini mutsuz hisseden bireyin, yaşamının diğer parçasında mutlu olması pek mümkün gözükmemektedir. Muhasebe meslek mensupları mükelleflerine ve kamuya hizmet sunan bireylerdir. Dolayısıyla, muhasebe mesleğini icra eden bireylerin yaşamda aldıkları doyum tüm toplumu ilgilendirmektedir. $\mathrm{Bu}$ araştırmanın amacı; büro sahibi bağımsız muhasebe meslek mensuplarının yaşam doyum düzeylerinin çeşitli faktörlere göre farklılaşıp farklılaşmadığını ortaya koymaktır. Tablo 1'deki faktör grupları göz önünde bulundurulduğunda mevcut çalışmada yaşam doyumuna etki eden faktörlerden kişisel faktörlerin, işle ilgili faktörlerin ve toplumsal faktörler grubunda değerlendirilen aile yapısıyla ilişkili faktörlerin ele alındığı söylenebilir.

\section{Literatür Özeti}

Aristo'ya göre mutluluk deneyim sonucu kazanılamayacağı gibi, insanın sahip olduğu diğer varlıklar, örneğin, menkuller ya da gayrimenkuller gibi de değildir. Aristo'ya göre insanların mutlu olması ve iyi bir hayatı elde edilebilmesi, fonksiyonlarını etkin kullanmasına bağlı olmaktadır. Bu bakış açısının doğal sonucu olarak; söz konusu fonksiyonlarla ilgili uygulamaların iyi yapılması durumunda, bireyin mutluluğu gerçekleşecektir (Işık ve Meriç, 2010: 423, 424). Pragmatist anlayışı temsil eden Bentham ve daha sonraki yıllarda Stuart'a göre en büyük mutluluk; en çok sayıda insana, en fazla iyiliğe neden olandır (Akgün, 2015: 27).

Yaşam doyumu sadece bir alana ya da bir kurama bağlı olmayıp, mülti-disipliner niteliktedir. Yaşam doyumunu bireysel açıdan açıklayan kuramlardan bazıları şunlardır (Şimşek, 2011: 31): (1) Aşağıdan yukarıya ve yukarıdan aşağı kuramları-Diener 1984, (2) duyuşsal, bilişsel ve birleşik kuramlar, (3) sonuç ve süreç kuramları ve (4) amaç ve gereksinim kuramları-Abraham Maslow'un Gereksinim Kuramı, M. Joseph Sirgy ve Jiyun Wu'nun Dengeli Yaşam Modeli ve Martha C. Nussbaum'un Nesnel Liste Kuramı amaç ve gereksinim kuramlarına örneklerdir (Batan, 2016: 16).

Şekil 1: Yaşam Doyumu ve Öznel İyi Olma iliş̧kisi

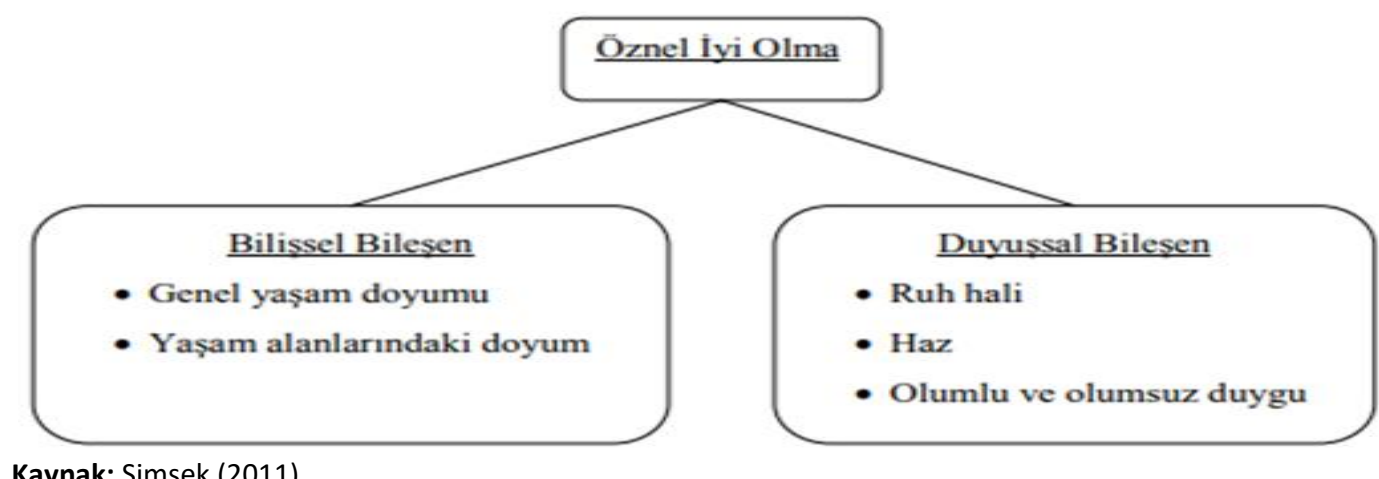

Kaynak: Şimşek (2011).

Diener'e göre (1984: 550) yaşam doyumu, öznel iyi oluşun bilişsel bir bileşeni ve bireyin yaşamıyla ilgili bilişsel yargılarını içermektedir (aktaran Dağlı ve Baysal, 2016: 1251). Öznel iyi oluş 
literatürü, insanların neden ve niçin kendi yaşamlarını pozitif yollardan değerlendirdikleri üzerinde durmaktadır (Yetim, 1991: 69). Bu çalışmaların kapsadığı kavramlar, mutluluk, doyum, moral ve olumlu duygu gibi kavramlardır (Vara, 1999: 17). Diener (1994) ve Proctor vd.'ne (2008) göre öznel iyi olma, bireyin yaşamına ilişkin bilişsel ve duyuşsal değerlendirmelerdir. Literatürde yaşam doyumu kavramının çoğunlukla öznel iyi olma yapısının altında bulunan bilişsel bileşen olarak incelendiği görülmektedir (aktaran Şimşek, 2011: 13). Diener'e (1994) göre doyum; bilişsel karara ilişkin bir deneyim olmasının yanı sıra mutluluk, duygu ve hislere de gönderme yapmaktadır (ibid., 3). Bahsedilen bu sınıflandırmaya göre yaşam doyumu ile öznel iyi olma ilişkisi Şekil 1'de açıklanmaktadır.

Diener ve Lucas'a (1999) göre yaşam doyumu; geçmişten doyum, gelecekten doyum, mevcut yaşamdan doyum, yaşamı değiştirme arzusu ve kişinin yakınlarının o kişinin yaşamı hakkındaki görüşlerini kapsamaktadır. Doyum alanları ise iş, aile, serbest zaman, sağlık, para, benlik ve kişinin yakın çevresi olabilmektedir (alıntılayan Tuzgöl Dost, 2007: 133). Diener (2000) yaşam doyumunu genel mutluluk açısından önemli bir unsur olarak görmekte ve yaşamdan hoşnutsuz olmanın genel stres belirtisi olduğunu dile getirmektedir. Çok sayıda faktörün yaşam doyumunu etkilediği düşünülmektedir. İş ve iş tecrübesi kişinin hayatında önemli bir kısmı oluşturur ve kişisel hedeflerin veya amaçların gerçekleştirilmesi ya da başarılması yaşam doyumunu artırmaktadır (alıntılayan Bulut Serin ve Aydınoğlu, 2013: 46). Baştemur, 32 ülkede yaşam doyumu ile ilgili yapılan 245 çalışmanın sonuçlarını incelemiş ve yaşam doyumuna etki eden faktörleri derlemiştir: (1) Özgürlük ve demokrasinin kabul gördüğü ekonomik yönden zengin bir ülkede yaşamak, (2) Politik istikrar, (3) Azınlıktan ziyade, çoğunluğun parçası olmak, (4) Toplumdaki sosyal katmanın üst grubunda yer almak, (5) Evli olmak, ailesi ve arkadaşları ile iyi ilişkiler içerisinde bulunmak, (6) Fiziksel ve ruhsal olarak sağlam olmak, (7) Açık fikirli ve aktif olmak, (8) Kendi hayatının kontrolünü elinde bulundurduğunu hissetmek, (9) Para kazanma ve politik olarak muhafazakâr olmak yerine, sosyal ve maddî değerlere sahip olmaya istekli olmak (alıntılayan Deveci, 2014: 59-60). Diğer yandan literatürde yaşam doyumunu etkileyen faktörlerin, işle ilgili faktörler, kişisel faktörler, çevresel faktörler ve toplumsal faktörler olarak dört kategoride de toplandığı görülmektedir (Özdevecioğlu ve Aktaş, 2007: 8). Tablo 1 bu kategorileri göstermektedir.

Tablo 1: Yaşam Doyumunu Etkileyen Faktörler

\begin{tabular}{ll}
\hline Kategori & Açıklama \\
\hline İş & $\begin{array}{l}\text { İşin niteliği, işin dışarıdan görünümü, alınan ücret, örgütteki rol, iş yükü, yükselme } \\
\text { imkânları, işyerinde verilen eğitimler, işle ilgili tecrübeler }\end{array}$ \\
Kişisel Faktörler & $\begin{array}{l}\text { Yaş, cinsiyet, eğitim durumu, kişilik özellikleri, bireyin negatif veya pozitif } \\
\text { duygusallıkları, beklentileri }\end{array}$ \\
Çevresel faktörler & $\begin{array}{l}\text { Alternatif iş bulma imkânları } \\
\text { Toplumsal }\end{array}$ \\
Faktörler & $\begin{array}{l}\text { Bireyin sosyal ağları, üye olunan sosyal organizasyonlar, aile ve akrabalar ile ilişkiler, } \\
\text { aile izolâsyonu, hemşerilik }\end{array}$ \\
\hline
\end{tabular}

Kaynak: Özdevecioğlu ve Aktaş (2007)

Gürel ve Gürel (2015) muhasebe meslek mensuplarının mesleki tükenmişlik düzeylerinin saptanması ve tükenmişlik düzeyi ile yasam doyumları arasındaki ilişkinin ortaya konulması amacıyla Aydın ilindeki serbest muhasebeci mali müşavirler üzerinde araştırma yapmıştır. Çalışmada, mesleki tükenmişliğin en önemli alt boyutlarından biri olan duygusal tükenmişliğin yasam doyumunu azalttığı sonucuna varılmış, ancak diğer alt boyutlar olan duyarsızlaşma ve kişisel başarısızlık ile yaşam doyumu arasında ise istatistikî olarak anlamlı bir ilişki bulamamışlardır. Güner, Çiçek ve Can (2014) banka çalışanlarının meslekî stres ve tükenmişlik düzeylerinin iş doyumu ve yaşam doyumu düzeyleri ile ilişkisini araştırmış; meslekî stres ile iş doyumu ve meslekî stres ile yaşam doyumu arasında negatif yönlü orta düzeyde ilişkinin olduğunu belirlemişlerdir. Ayrıca, tükenmişlik ile iş doyumu ve tükenmişlik ile yaşam doyumu arasında da negatif yönlü ilişkinin varlığını, son olarak da iş doyumu ile yaşam doyumu arasında pozitif yönlü güçlü bir ilişkinin 
olduğunu saptamışlardır. Şimşek ve Aktaş (2014) örgütsel sessizlik, kişilik ve yaşam doyumu arasındaki etkileşimi araştırmışlar ve analiz sonuçlarına göre kabullenici ve savunmacı sessizlik arttıkça yaşam doyumunun azaldığı sonucuna varmışlardır. Telef (2011) öğretmenlerin öz-yeterlikleri, iş doyumları, yaşam doyumları ve tükenmişliklerini incelemiş; öz-yeterliğin alt boyutlarından öğrenci katılımını sağlama, öğretim stratejileri ve sınıf yönetimi yeterliklerinin, öğretmenlerin iş doyumları ve yaşam doyumları ile pozitif ilişkili olduğunu ve tükenmişlikleri ile negatif ilişkili olduğunu görmüştür. Ayrıca demografik değişkenlerin, öğretmenlerin öz-yeterlikleri, iş doyumları, yaşam doyumları ve tükenmişlikleri üzerinde farklılıklara yol açtığını saptamıştır.

Yılmaz ve Altınok (2009), okul yöneticilerinin yalnızlık ve yaşam doyum düzeylerini incelemiş; gelir düzeyi değişkenine göre, okul yöneticilerinin yalnızlık puan ortalamalarında anlamlı bir farklılık bulamazken, yaşam doyumlarının puan ortalamalarında anlamlı bir farklılık bulmuştur. Ayrıca, okul yöneticilerinin yalnızlık ile yaşam doyum düzeyleri arasında negatif yönlü bir ilişki saptamıştır. Ülker Tümlü ve Recepoğlu (2013), üniversite akademik personelinin psikolojik dayanıklılığı ile yaşam doyumu arasındaki ilişkiyi araştırmışlar; personelin yaşam doyumu ile psikolojik dayanıklılığı arasında orta düzeyde, pozitif yönde anlamlı bir ilişki bulmuş, psikolojik dayanıklıı̆ğın yaşam doyumunu anlamlı bir şekilde yordayıp, psikolojik dayanıklılığa ilişkin toplam varyansın yüzde yedisini açıkladığını ifade etmişlerdir. Ayrıca, üniversite akademik personelinin psikolojik dayanıklılık düzeylerinin cinsiyete, yaşa, medeni duruma, unvana, hizmet yılına ve bulundukları üniversitedeki hizmet yılına göre anlamlı şekilde farklılık göstermediğini bulmuşlardır. Recepoğlu (2013), öğretmen adaylarının yaşam doyumları ile öğretmenlik mesleğine ilişkin tutumları arasındaki ilişkiyi incelemiş; yaşam doyumu ile öğretmenlik mesleğine ilişkin tutum arasında orta düzeyde pozitif yönde anlamlı bir ilişki bulmuştur. Araştırmaya göre, yaşam doyumu öğretmenlik mesleğine ilişkin tutumu anlamlı bir şekilde yordamakta ve ilgili tutuma ilişkin toplam varyansın yüzde 23'ünü açıklamaktadır. Yine araştırma sonuçlarına göre, öğretmen adaylarının yaşam doyumları yaşa, öğrenim türüne, öğrenim gördüğü bölüme ve ailede öğretmen olup olmamasına göre anlamlı şekilde farklılık göstermezken; cinsiyete ve üniversiteye yerleşme sırasına göre anlamlı şekilde değişmektedir.

Çeşitli araştırmacılar yaşam doyumu ile farklı unsurlar arasındaki ilişkiler incelemişlerdir. Örneğin, üniversite öğretim elemanları üzerinde yapılan bir uygulamayla yaşam doyumu ile duygusal zekâ ve mizah tarzı arasındaki ilişki araştırılmıştır (Tümkaya vd., 2008). Doğan vd. (2012) rehabilitasyon merkezinde çalışan sağlık personelinde iş ve yaşam doyumunu araştırmıştır. Tekir vd. (2016) sağlık çalışanlarının tükenmişlik, iş doyumu düzeyleri ve yaşam doyumunu incelemiştir. Bunun dışında yaşam doyumu konusunun herhangi bir başka unsurla birlikte araştırılmadığı çalışmalar da bulunmaktadır, ancak bunlar çoğunlukla herhangi bir meslek grubunu kapsamamakta, çoğunlukla lise ve/veya üniversite öğrencileri üzerine uygulanmaktadır. Yine araştırmalarda çoğunlukla yaşam doyumu değil, iş doyumu üzerine çalışılmıştır. Buradan, muhasebe meslek mensupları üzerine yaşam doyumunu inceleyen yeterli sayıda çalışma bulunmadığı görülmektedir. Ayrıca muhasebe meslek mensupları söz konusu olduğunda bağımlı-bağımsız çalışan ayırımının da yapılmadığı, hatta analizlerde buna dikkat edilmediği de görülmektedir.

Bunun yanı sıra, yaşamdan duyulan memnuniyetin çok sayıda unsurdan etkileneceği, içinde bulunulan duruma, koşullara, zamana, yaşa, icra edilen mesleğe ve araştırmaya katılanların yaşadığı coğrafi bölgeye göre de değişeceği aşikârdır.

\section{3. Çalışmanın Amacı}

Bu araştırmanın amacı; büro sahibi bağımsız muhasebe meslek mensuplarının yaşam doyum düzeylerinin çeşitli faktörlere göre farklılaşıp farklılaşmadığını ortaya koymaktır. Tablo 1'deki faktör grupları göz önünde bulundurulduğunda mevcut çalışmada yaşam doyumuna etki eden faktörlerden kişisel faktörlerin, işle ilgili faktörlerin ve toplumsal faktörler grubunda değerlendirilen aile yapısıyla ilişkili faktörlerin ele alındığı söylenebilir. 


\section{1. Çalışmanın Hipotezleri}

Çalışmanın hipotezleri aşağıdaki gibi kurulmuştur: (1) Yaşın yaşam doyum düzeyi üzerinde etkisi vardır, (2) Cinsiyetin yaşam doyum düzeyi üzerinde etkisi vardır, (3) Medenî durumun yaşam doyum düzeyi üzerinde etkisi vardır, (4) Çalışanların bakmakla yükümlü oldukları kişi sayısının yaşam doyum düzeyi üzerinde etkisi vardır, (5) Meslekte geçen sürenin yaşam doyum düzeyi üzerinde etkisi vardır, (6) Mesleği isteyerek seçmenin yaşam doyum düzeyi üzerinde etkisi vardır.

\section{2. Çalışmanın Yöntemi}

Diener vd. (1985: 72) tarafından geliştirilen Yaşam Doyumu Ölçeği'nin özgün formu tek faktör, beş madde ve Likert tipinde yedili derecelendirmeden oluşan kendini değerlendirme ölçeğidir. Her bir madde, yedili derecelendirilmiş cevaplama sistemine, yani "1=Kesinlikle Katılmıyorum" ile "7=Tamamen Katılıyorum" ve aradaki seçeneklere göre değerlendirilmektedir. İgili ölçek daha önce de Köker (1991) tarafından Türkçeye uyarlanmış ve yedili derecelendirme olarak Türkiye'de değişik araştırmacılar tarafından kullanılmıştır.

Tablo 2: Puanların Değerlendirilmesi

\begin{tabular}{clc}
\hline $\begin{array}{c}\text { Maksimum } \\
\text { Puan 35 }\end{array}$ & \multicolumn{1}{c}{$\begin{array}{c}\text { Orijinal 7'li Ölçeğe Göre Alınan } \\
\text { Puanların Değerlendirilmesi }\end{array}$} & $\begin{array}{c}\text { Araştırmada Kullanılan 5'li Ölçeğe Göre } \\
\text { Alınabilecek Olan Maksimum 25 Puan } \\
\text { Üzerinden Puanların Değerlendirilmesi }\end{array}$ \\
\hline $31-35$ & Son Derece memnun & $22,1428-25,0000$ \\
$26-30$ & Memnun & $18,5714-22,1427$ \\
$21-25$ & Biraz Memnun & $15,0000-18,5713$ \\
20 & Nötr - Ne memnun, ne memnun değil & $14,2857-14,9999$ \\
$15-19$ & Biraz Memnuniyetsiz & $10,7142-14,2856$ \\
$10-14$ & Memnuniyetsiz & $7,1428-10,7141$ \\
$5-9$ & Son Derece Memnuniyetsiz & $5,0000-7,1427$ \\
\hline
\end{tabular}

Kaynak: Fetzer Institute. Self Report Measures for Love and Compassion Research: Satisfaction

Ölçeğin Türkçeye uyarlanması sırasında, özgün formunda yedi basamaklı olan cevap seçeneklerinin Türk kültürüne uygun olmadığı görülünce basamak sayısı beşe indirilmiştir. Bu sistemde ölçekteki ifadelerin puanlanması; Hiç katılmıyorum (1), Çok az katılıyorum (2), Orta düzeyde katılıyorum (3), Büyük oranda katılıyorum (4) ve Tamamen Katılıyorum (5) şeklindedir (Dağlı ve Baysal, 2016: 1252). Çalışmada, yaşam doyumu düzeylerinin incelenmesine ilişkin olarak Yaşam Doyumu Ölçeği ve araştırmacılar tarafından oluşturulan Kişisel Bilgi Formu kullanılmıştır. Google Forms kullanılarak oluşturulan form, 3 Şubat 2018 tarihinde Türmob internet sitesinde (www.turmob.org.tr) yer alan 77 SMMM odasının ve sekiz YMM odasının listelerde bulunan e-posta adreslerine gönderilmiş ve oda mensuplarıyla paylaşııması istenmiştir. Adreslerden bazıları hata verdiğinden, bu odaların internet sitelerine ayrıca girilerek varsa farklı e-posta adresleri yeniden toplanmış ve bu adreslere gönderim yapılmıştır. Ayrıca odalar telefonla aranmış ve ilgili kişilerden, anketin oda mensuplarıyla paylaşılması istenmiştir.

\section{Ampirik Bulgular}

Ankete, ikisi Serbest Muhasebeci (SM), 74'ü Serbest Muhasebeci Mali Müşavir (SMMM) ve ikisi Yeminli Mali Müşavir (YMM) olmak üzere 78 bağımsız çalışan büro sahibi muhasebe meslek mensubu katılmışır. Toplanan verilerin analizi için IBM SPSS Statistics 20 programından yararlanılmıştır. Toplanan verilere ait betimleyici istatistikler ayrıntılı olarak verilmiştir. Pearson Korelâsyon Analizi sonucunda çalışanların Yaşam Doyumu düzeyleri ile Meslekte Geçirdikleri Süreler, Bakmakla Yükümlü Oldukları Kişi Sayıları ve Yaşları arasında herhangi bir ilişki bulunamamıştır. Ayrıca, bağımsız örneklem t-testi ile çalışanların Cinsiyetlerine, Medenî Durumlarına ve Mesleği İsteyerek Seçip Seçmemelerine göre yaşam doyumu düzeylerinde istatistiksel olarak anlamlı bir farklılık olup olmadığı araştırılmış; yalnızca mesleği isteyerek seçip seçmemelerine göre yaşam doyumu düzeylerinde istatistiksel olarak anlamlı bir farklılığa rastlanmıştır $(p<0,05)$. 
Tablo 3: SM, SMMM ve YMM'lere İlişkin Betimsel İstatistikler

\begin{tabular}{lrr}
\hline Eğitim Durumu & Frekans & Oran (\%) \\
\hline Lise & 4 & 5,1 \\
Önlisans & 3 & 3,8 \\
Lisans Örgün Öğretim & 36 & 46,2 \\
Açık Öğretim Fakültesi & 27 & 34,6 \\
Lisansüstü & 8 & 10,3 \\
TOPLAM & $\mathbf{7 8}$ & $\mathbf{1 0 0 , 0}$ \\
\hline Çalışma Alanı & Frekans & Oran (\%) \\
Defter Tutma & 73 & 26,6 \\
SGK ile ilişkiler & 55 & 20,1 \\
Vergi Dairesi ile ilişkiler & 54 & 19,7 \\
Şirket Kuruluş & 41 & 15,0 \\
Şirket Kapanış & 31 & 11,3 \\
Tasdik & 20 & 7,3 \\
TOPLAM & $\mathbf{2 7 4}$ & $\mathbf{1 0 0 , 0}$ \\
\hline Mükellef Büyüklükleri & Frekans & Oran (\%) \\
Mikro - işveren dahil 1 ilâ 9 çalışan & 62 & 55,4 \\
Küçük - işveren dahil 10 ilâ 49 çalışan & 36 & 32,1 \\
Orta - işveren dahil 50 ilâ 249 çalışan & 12 & 10,7 \\
Büyük - işveren dahil çalışan sayısı 250'den fazla & 2 & 1,8 \\
TOPLAM & $\mathbf{1 1 2}$ & $\mathbf{1 0 0 , 0}$ \\
\hline
\end{tabular}

Tablo 3'ten anlaşıldığı üzere, SM, SMMM ve YMM'lerin yüzde 46,2'si Lisans Örgün Öğretim mezunu, yüzde 34,6'sı Açık Öğretim Fakültesi mezunudur. Katılımcıların yüzde 94,87'sinin SMMM olduğu göz önünde bulundurulduğunda, Defter tutma faaliyetinin yüzde 26,6, SGK ile ilişkilerin yüzde 20,1 ve vergi dairesiyle ilişkilerin yüzde 19,7 olması doğaldır. Daha önce bahsedildiği gibi anketler 77 SMMM odasına ve sekiz YMM odasına gönderilmiştir. YMM unvanlı meslek mensubu sayısının göreceli olarak az olduğu düşünüldüğünde, büroda mükelleflere verilen hizmetlerin görünümünün bu şekilde olması doğaldır. Yine, tamamen bu çalışmanın anketini yanıtlayan meslek mensupları bağlamında olmakla beraber, mükellefleri mikro büyüklükte işletme olan meslek mensubu oranı yüzde 55,4'tür. Bunu ağırlıklı olarak küçük işletme mükelleflere hizmet veren meslek mensupları yüzde 32,1 ile takip etmektedir.

Tablo 4'te SM, SMMM ve YMM'lerin hizmet verdikleri mükelleflerinin faaliyet gösterdikleri sektörler yer almaktadır. Mükellef sayısına bakıldığında ve meslek mensubunun verdiği hizmetler göz önünde bulundurulduğunda; perakende ticaret erbabı, muhtemelen küçük müteahhitler ve esasen küçük tüccar addedilebilecek olan gıda, içki, tütün sektörlerinin birlikte ve yaklaşık olarak yüzde 30'luk dilimi oluşturması doğaldır. Kurumsal yapıları itibarıyla menkul kıymetler şirketlerinin, bankaların ve kamu kurumlarının listede yer almaması beklenen bir durumdur.

Yapılan istatistikî analizler sonucunda, SM, SMMM ve YMM'lerin yaşları ile yaşam doyumu düzeyleri arasında istatistiksel olarak anlamlı bir doğrusal ilişkiye rastlanmamıştır. Benzer şekilde katılımcıların meslekte geçirdikleri süreler ile yaşam doyumu düzeyleri arasında istatistiksel olarak anlamlı bir doğrusal ilişkiye de rastlanmamıştır. SM, SMMM ve YMM'lerin bakmakla yükümlü oldukları kişi sayısı ile yaşam doyumu düzeyleri arasında istatistiksel olarak anlamlı bir doğrusal ilişki de bulunmamıştır. 
Tablo 4: SM, SMMM ve YMM'lerin Mükelleflerinin Faaliyet Gösterdikleri Sektörler

\begin{tabular}{|c|c|c|c|c|c|}
\hline $\begin{array}{l}\text { Mükelleflerin Faaliyet } \\
\text { Gösterdikleri Sektörler }\end{array}$ & Frekans & $\begin{array}{c}\text { Oran } \\
(\%)\end{array}$ & $\begin{array}{l}\text { Mükelleflerin Faaliyet } \\
\text { Gösterdikleri Sektörler }\end{array}$ & Frekans & $\begin{array}{c}\text { Oran } \\
(\%)\end{array}$ \\
\hline Perakende Ticaret & 52 & 10,9 & $\begin{array}{l}\text { Meslekî, Bilimsel ve Teknik } \\
\text { Faaliyetler }\end{array}$ & 11 & 2,3 \\
\hline İnşaat ve Bayındırlık & 44 & 9,2 & Orman Ürünleri ve Mobilya & 11 & 2,3 \\
\hline Gıda, İçki ve Tütün & 44 & 9,2 & $\begin{array}{l}\text { Metal Eşya, Makine ve Gereç } \\
\text { Yapım }\end{array}$ & 10 & 2,1 \\
\hline Lokanta ve Oteller & 41 & 8,6 & Bilişim & 9 & 1,9 \\
\hline Toptan Ticaret & 39 & 8,1 & İdarî ve Destek Hizmetleri & 6 & 1,3 \\
\hline Diğer & 38 & 7,9 & $\begin{array}{l}\text { Kâğıt ve Kâğıt Ürünleri, Basım \& } \\
\text { Yayın }\end{array}$ & 6 & 1,3 \\
\hline Tarım ve Hayvancılık & 25 & 5,2 & Taşıt Araçları Sanayii & 6 & 1,3 \\
\hline $\begin{array}{l}\text { Eğitim, Sağlık, Spor \& Dğ.Sosyal } \\
\text { Hzm. }\end{array}$ & 21 & 4,4 & Elektrik Gaz ve Su & 5 & 1,0 \\
\hline Gayrimenkul Faaliyetleri & 18 & 3,8 & Taş ve Toprağa Dayalı & 3 & 0,6 \\
\hline Dokuma, Giyim Eşyası ve Deri & 17 & 3,5 & Teknoloji & 3 & 0,6 \\
\hline $\begin{array}{l}\text { Ulaştırma, Haberleşme ve } \\
\text { Depolama }\end{array}$ & 15 & 3,1 & Balıkçılık ve Su Ürünleri & 2 & 0,4 \\
\hline Sigorta Şirketleri & 14 & 2,9 & Mali Kuruluşlar & 2 & 0,4 \\
\hline $\begin{array}{l}\text { Kimya, Petrol, Kauçuk \& Plstk. } \\
\text { Ürünler }\end{array}$ & 13 & 2,7 & Metal Ana Sanayi & 1 & 0,2 \\
\hline Kiralama ve İş Faaliyetleri & 11 & 2,3 & $\begin{array}{l}\text { Ormancilık ve Orman } \\
\text { İşletmeciliği }\end{array}$ & 1 & 0,2 \\
\hline Madencilik & 11 & 2,3 & TOPLAM & 479 & 100,0 \\
\hline
\end{tabular}

Tablo 5: SM, SMMM ve YMM'lerin Yaşları, Kıdemleri ve Bakmakla Yükümlü Oldukları Kişi Sayısı ile Yaşam Doyumu Düzeyleri Arasındaki i̇lişki

\begin{tabular}{lcc}
\hline & Pearson Korelâsyon Katsayısı (r) & Anlamlılık \\
\hline Yaş \& Yaşam Doyumu & 0,201 & 0,078 \\
Meslekte geçen süre \& Yaşam Doyumu & 0,091 & 0,426 \\
Bakmakla yükümlü olunan kişi sayısı \& Yaşam Doyumu & 0,101 & 0,379 \\
\hline
\end{tabular}

SM, SMMM ve YMM'lerin yaşam doyumu düzeylerinde cinsiyetlerine ve medenî durumlarına göre istatistiksel olarak anlamlı bir farklılık bulunamamıştır. Ancak yaşam doyumu düzeylerinde mesleği isteyerek seçip seçmemelerine göre istatistiksel olarak anlamlı bir fark bulunmuştur $(p<0,05)$. Mesleğini kendisi isteyerek seçenlerin yaşam doyumu düzeyleri $(15,96 \pm 4,79)$ diğerlerine $(13,69 \pm 4,65)$ göre anlamlı derecede daha yüksektir.

Tablo 6: SM, SMMM ve YMM'lerin Cinsiyetlerine, Medenî Durumlarına, Mesleği İsteyerek Seçip Seçmemelerine Göre Yaşam Doyumu Ortalamalarına ait t-Testi Sonuçları

\begin{tabular}{|c|c|c|c|c|c|c|c|}
\hline & & $\mathbf{n}$ & Ortalama & $\begin{array}{l}\text { Standart } \\
\text { Sapma }\end{array}$ & $\mathbf{t}$ & sd & Anlamlılık \\
\hline Yaşam & Kadın & 17 & 14,7059 & 4,55199 & \multirow{2}{*}{$-0,392$} & \multirow{2}{*}{76} & \multirow{2}{*}{0,696} \\
\hline Doyumu & Erkek & 61 & 15,2295 & 4,94433 & & & \\
\hline Yaşam & Bekâr & 10 & 13,8000 & 4,84883 & \multirow{2}{*}{$-0,920$} & \multirow{2}{*}{76} & \multirow{2}{*}{0,360} \\
\hline Doyumu & Evli & 68 & 15,3088 & 4,84154 & & & \\
\hline \multirow{2}{*}{$\begin{array}{l}\text { Yaşam } \\
\text { Doyumu }\end{array}$} & Kendim & 49 & 15,9592 & 4,79131 & \multirow{2}{*}{2,043} & \multirow{2}{*}{76} & \multirow{2}{*}{0,044} \\
\hline & Diğer* & 29 & 13,6897 & 4,65298 & & & \\
\hline
\end{tabular}

*Diğer: 1) Ailemin isteğiyle, 2) Baba/aile mesleği olduğu için, 3) Başka seçeneğim olmadığı için, 4) Tesadüfen

Çalışmaya katılan SM, SMMM ve YMM'lerin yaşam doyumunu temsil eden beş ifadeye verdikleri yanıtlar sonucunda Yaşam Doyumu Toplam Puanı ortalaması 15,1154 olmuştur. 
Alınabilecek olan en yüksek puan göz önünde bulundurulduğunda çalışmaya katılan muhasebe meslek mensuplarının yüzde 60 yaşam doyumuna sahip olduğu söylenebilir.

Tablo 7: SM, SMMM ve YMM'lerin Yaşam Doyumu Düzeyleri

\begin{tabular}{|c|c|c|c|}
\hline Alınabilir Minimum Puan 5 ve Alınabilir Maksimum Puan 25'tir & n & $\begin{array}{c}\text { Toplamların } \\
\text { Ortalaması } \\
\end{array}$ & $\begin{array}{c}\text { Standart } \\
\text { Sapma }\end{array}$ \\
\hline Yaşam Doyumu Toplam Puanı* & 78 & 15,1154 & 4,83757 \\
\hline $\begin{array}{l}\text { Yaşam Doyum Ölçeği Maddelerine ait Ortalama ve Standart Sapma } \\
\text { Değerleri }\end{array}$ & & Ortalama & $\begin{array}{l}\text { Standart } \\
\text { Sapma }\end{array}$ \\
\hline 1. İdeallerime yakın bir yaşantım vardır. & & 3,0000 & 1,09307 \\
\hline 2. Yaşam koşullarım mükemmeldir. & & 2,9103 & 1,08336 \\
\hline 3. Yaşamımdan memnunum. & & 3,3974 & 1,19891 \\
\hline 4. Şimdiye kadar yaşamdan istediğim önemli şeylere sahip oldum. & & 3,4487 & 1,11247 \\
\hline $\begin{array}{l}\text { 5. Tekrar dünyaya gelsem hayatımdaki hemen hemen hiçbir şeyi } \\
\text { değiştirmezdim. }\end{array}$ & & 2,3590 & 1,40476 \\
\hline
\end{tabular}

*Elde edilen yüksek puan yaşam doyumunun fazla olduğunun göstergesidir.

\section{Sonuç}

Serbest çalışan muhasebe meslek mensuplarının yaşam doyumu düzeylerinin incelendiği bu çalışmanın sonucunda, katılımcıların yaşam doyumu düzeylerinde cinsiyetlerine ve medenî durumlarına göre istatistiksel olarak anlamlı bir farklılık bulunamamıştır. Ancak yaşam doyumu düzeylerinde mesleği isteyerek seçip seçmemelerine göre, istatistiksel olarak anlamlı bir fark bulunmuştur. Katılımcıların yaşları, meslekte geçirdikleri süreler ve bakmakla yükümlü oldukları kişi sayısı ile yaşam doyumu düzeyleri arasında istatistiksel olarak anlamlı bir doğrusal ilişkiye rastlanmamıştır. Çalışmaya katılan serbest çalışan muhasebe meslek mensuplarının yaşam doyumu puan ortalaması 15,1154 'tür. Böylelikle yaşamlarından biraz memnun oldukları sonucu ortaya çıkmaktadır.

Demografik faktörler göz önünde bulundurulduğunda anketi yanıtlayanlar arasında göreceli olarak en mutsuz olanların mesleğini kendi seçemeyenler-13,6897 puan- olduğu, bu grubu serbest çalışan muhasebe meslek mensuplarından bekâr olanlar-13,8000 - takip etmektedir. Bu iki grup yaşamlarından biraz memnuniyetsiz olan kesimdir. Serbest çalışan muhasebe meslek mensuplarından kadın olanlar 14,7059 yaşam doyumu puan ortalamasıyla yaşamlarından ne memnun ne memnun değil olarak tanımlanabilirler. Yine Tablo 2'ye göre erkek muhasebe meslek mensupları 15,2295 puan ile, evli muhasebe meslek mensupları 15,3088 puan ile ve mesleğini kendi seçme şansını bulmuş olan serbest çalışan muhasebe meslek mensupları 15,9592 puan ile yaşamlarından biraz memnun olan grupları oluşturmaktadır.

Hatırlamak gerekirse; Baştemur tarafından yapılan incelemenin-32 ülke/245 çalışmasonucunda derlenen yaşam doyumuna etki eden faktörler arasında özgürlük ve demokrasinin kabul gördüğü ekonomik yönden zengin bir ülkede yaşamak, azınlıktan ziyade, çoğunluğun parçası olmak, evli olmak, ailesi ve arkadaşları ile iyi ilişkiler içerisinde bulunmak, kendi hayatının kontrolünü elinde bulundurduğunu hissetmek bulunmaktadır. Bu açıdan değerlendirildiğinde ankete katılan kadın serbest çalışan muhasebe meslek mensupları katılımcıların yüzde 21,79'unu oluşturmaktadır. Gürel ve Gürel'in (2015) çalışmasında da kadınların oranı yüzde 20,13'tür. Mesleğin erkek egemen bir meslek olduğu bilinmektedir. Bu durum kadınları azınlık konumuna itmektedir. Baştemur'un derlemesinde azınlığa dahil olmanın yaşam doyumu üzerinde negatif etkileri olduğu belirtilmiştir. Buradan yola çıkıldığında çalışmaya katılan kadın muhasebe meslek mensuplarının düşük puanı anlam kazanmaktadır. Özgürlük, özgür seçim yapabilme hakkını da beraberinde getirmelidir. Özgürlük aynı zamanda bireyin kendi hayatının kontrolünü elinde bulundurduğunu hissetmesi anlamına da gelir. Buradan yola çıkıldığında Baştemur'un derlemesinin sonuçlarının ışığında, çalışmamızda en yüksek yaşam doyumu puanına, mesleğini kendi seçmiş olanların sahip olması daha anlaşılır olmaktadır. 
Çalışmaya katılanlarla sınırlı olmak üzere; ideallerine yakın bir yaşantısı olduğunu düşünen serbest çalışan muhasebe meslek mensuplarının oranı ortalama olarak yüzde 60'tır. Yaşam koşullarının mükemmel olduğunu düşünenlerin oranı yüzde 58,21'dir. Genel olarak yaşamından memnun olduğunu belirtenlerin oranı yüzde 67,95 olurken, yaşamdan istediği önemli şeylere hâlihazırda sahip olduğunu düşünenlerin oranı yüzde 68,97'dir. Kabul edilebilir memnuniyet seviyelerine rağmen Yaşam Doyum Ölçeğinde yer alan son soruya verilen yanıtlar düşündürücüdür. Tekrar dünyaya gelsem hayatımdaki hemen hemen hiçbir şeyi değiştirmezdim ifadesine verilen cevapların puan ortalaması 2,36'dır, bu da yüzde $47,18^{\prime}$ lik bir orana tekabül etmektedir. Serbest çalışan muhasebe meslek mensuplarının yaşamdan bir şekilde memnun olmaları, tekrar dünyaya gelseler hayatlarındaki hemen hemen hiçbir şeyi değiştirmeyecekleri sonucunu doğurmamaktadır.

Serbest çalışan muhasebe meslek mensuplarının yaşam doyumu düzeyleri ile ilgili yapılacak daha sonraki çalışmalarda örneklem sayısının artırıması, yaşam doyumu düzeyine etki eden faktörlerin açıklanması bakımından faydalı olacağı düşünülmektedir. Yalnızca örneklem sayısının artııılması ve etki eden faktörlerin ortaya çıkarılması değil, yanı sıra farklı mesleklerin mensuplarının yaşam doyumu puanlarının da değerlendirilmesi, Türk toplumu açısından geniş alan çalışmalarının gerçekleştirilmesi daha mutlu, yaşam doyumuna yakalamış bireyler yaratmak açısından önemlidir. Bunlar belirlendiğinde akademinin ve meslek odalarının birlikte izleyecekleri yol haritaları da ortaya çıkacaktır.

\section{Kaynakça}

Akgün, E. (2015). Lise Öğretmenlerinin Psikolojik Sermaye Düzeyleri İle Yaşam Doyumu Düzeyleri Arasındaki İlişki, Yayınlanmamış Yüksek Lisans Tezi, Kahramanmaraş Üniversitesi, Sosyal Bilimler Enstitüsü, Gaziantep.

Batan, S. N. (2016). Yetişkinlerde Psikolojik Dayanıklılık ve Dini Başa Çıkmanın Yaşam Doyumuna Etkileri, Yayınlanmamış Doktora Tezi, Marmara Üniversitesi, Sosyal Bilimler Enstitüsü, İstanbul.

Bulgurcu Gürel, E. B., ve Gürel, E. (2015). Muhasebe Meslek Mensuplarının Mesleki Tükenmişlik Düzeyinin Yaşam Doyumu Üzerine Etkisi: Aydın İli Örneği. Accounting \& Auditing Perspective Magazine / Muhasebe ve Denetime Bakış, 14(44), 37-48, 13.05.2018.

Bulut Serin, N. ve Aydınoğlu, N. (2013). Investigation of Life Satisfaction Predictors of School Counsellors, Eurasian Journal of Educational Research, 53, 345-360.

Çelik, M. (2016). Tükenmişlik Yaşam Doyumu ve Iş̧ Yükü Illişkisi: Denizli'de Faaliyet Gösteren Muhasebe Meslek Mensupları Üzerinde Bir Araştırma, Süleyman Demirel Üniversitesi iktisadi ve Idari Bilimler Dergisi, 21(4), 1139-1152.

Dağlı, A. ve Baysal, N. (2016). Yaşam Doyumu Ölçeğinin Türkçeye Uyarlanması: Geçerlik ve Güvenirlik Çalışması. Elektronik Sosyal Bilimler Dergisi. ISSN: 1304-0278. Güz-2016 15(59), 1250-1262.

Deveci, S. (2014). Sağlık Çalışanlarında İş Doyumu ve Yaşam Doyumu iliş̧kisi (Antalya Atatürk Devlet Hastanesi Hemşireler Örneği), Yayınlanmamış Yüksek Lisans Tezi, Beykent Üniversitesi, Sosyal Bilimler Enstitüsü, İstanbul.

Diener, E., Emmons, R. A., Larsen, R. J. ve Griffin, S. (1985). The Satisfaction with Life Scale. Journal of Personality Assessment, 49(1), 71-75.

Doğan, A., Deniz, M. E., Odabaş, H., Özyeşil, Z. ve Özgirgin, N. (2012). Rehabilitasyon Merkezinde Çalışan Sağlık Personelinde iş ve Yaşam Doyumu. Türkiye Fiziksel Tıp ve Rehabilitasyon Dergisi 58, 16-21. 
Dursun, S., Kaya, U. ve İştar, E. (2015). Kişilik - İş Uyumunun Duygusal Tükenmişlik ile İş ve Yaşam Doyumu Üzerindeki Etkisi: Muhasebe Meslek Mensupları Üzerinde Bir Uygulama, KTU SBE Sos. Bil. Derg., (9), 55-69.

Fetzer Institute (2009). Self Report Measures for Love and Compassion Research: Satisfaction.

Güner, F., Çiçek, H. ve Can, A. (2014). Banka Çalışanlarının Mesleki Stres ve Tükenmişlik Düzeylerinin İş Doyumu ve Yaşam Doyumu Düzeyleri İle iliş̧kisi. Uluslararası Alanya işletme Fakültesi Dergisi, 6(3), 59-76.

Işık, A. ve Meriç, M. (2010). Hayatın Kalitesi (Quality of Life) Kavramının Felsefik Temelleri; Aristo, Bentham ve Nordenfelt, Ege Akademik Bakış, 10 (1), 421-434.

Özdevecioğlu, M. ve Aktaş, A. (2007). Kariyer Bağlılığı, Mesleki Bağlılık ve Örgütsel Bağlılığın Yaşam Tatmini Üzerindeki Etkisi, Erciyes Üniversitesi Iktisadi ve Idari Bilimler Fakültesi Dergisi, 28, $1-20$.

Özer, M. ve Özsoy Karabulut, Ö. (2003). Yaşlılarda Yaşam Doyumu, Geriatri, 6(2), 72-74.

Recepoğlu, E. (2013). Öğretmen Adaylarının Yaşam Doyumları ile Öğretmenlik Mesleğine Ilişkin Tutumları Arasındaki Iliş̧kinin İncelenmesi. Hacettepe Üniversitesi Eğitim Fakültesi Dergisi Özel Sayı (1), 311-326.

Şimşek, E. (2011). Örgütsel Illetişim ve Kişilik Özelliklerinin Yaşam Doyumuna Etkileri, Yayınlanmamış Doktora Tezi, Anadolu Üniversitesi, Sosyal Bilimler Enstitüsü, Eskişehir.

Şimşek, E. ve Aktaş, H. (2014). Örgütsel Sessizlik ile Kişilik ve Yaşam Doyumu Etkileşimi: Kamu Sektöründe Bir Araştırma. Anadolu Üniversitesi Sosyal Bilimler Dergisi. 14(2), 121-136.

Tekir, Ö., Çevik, C., Arık, S. ve Ceylan, G. (2016). Sağlık Çalışanlarının Tükenmişlik, İş Doyumu Düzeyleri ve Yaşam Doyumunun İncelenmesi. Kırıkkale Üniversitesi Tıp Fakültesi Dergisi 18(2), 51-63.

Telef, B. B. (2011). Öğretmenlerin Öz-yeterlikleri, İş Doyumları, Yaşam Doyumları ve Tükenmişliklerinin İncelenmesi. Ilköğretim Online, 10(1), 91-108, 2011.

Tuzgöl Dost, M. (2003). Üniversite Öğrencilerinin Yaşam Doyumunun Bazı Değişkenlere Göre İncelenmesi, Pamukkale Üniversitesi Eğitim Fakültesi Dergisi, 22, 132-143.

Tümkaya, S., Hamarta, E., Deniz, M. E., Çelik, M. ve Aybek, B. (2008). Duygusal Zekâ Mizah Tarzı ve Yaşam Doyumu: Üniversite Öğretim Elemanları Üzerine Bir Araştırma. Türk Psikolojik Danışma ve Rehberlik Dergisi 3(30), 1-18.

Ülker Tümlü, G. ve Recepoğlu, E. (Aralık 2013). Üniversite Akademik Personelinin Psikolojik Dayanıklılık ve Yaşam Doyumu Arasındaki İlişki. Yükseköğretim ve Bilim Dergisi, 3(3), 205213.

TÜRMOB (2018). Odalar. http://www.turmob.org.tr/Odalar/YMM.

Vara, Ş. (1999). Yoğun Bakım Hemşirelerinde İş Doyumu ve Genel Yaşam Doyumu Arasındaki İlişkinin İncelenmesi, Yayınlanmamış Yüksek Lisans Tezi, Ege Üniversitesi Sağlık Bilimleri Enstitüsü, İzmir.

Yetim, Ü. (1991). Kişisel Projelerin Organizasyonu ve Örüntüsü Açısından Yaşam Doyumu, Yayınlanmamış Doktora Tezi, Ege Üniversitesi, Sosyal Bilimler Enstitüsü, İzmir.

Yılmaz, E. ve Altınok, V. (2009). Okul Yöneticilerinin Yalnızlık ve Yaşam Doyum Düzeylerinin İncelenmesi. Kuram ve Uygulamada Eğitim Yönetimi. 15(59), 451-469. 


\section{SELF-EMPLOYED ACCOUNTANTS' LIFE SATISFACTION LEVELS}

\section{Extended Abstract}

Aim: Factors influencing life satisfaction, which is one of the most important objectives in humans' lives, are examined in this study. Life satisfaction refers to a cognitive judgmental process. Shin and Johnson (1978) define life satisfaction as a global assessment of a person's quality of life according to his/her chosen criteria (quoted by Diener et al. (1985). There are many factors influencing life satisfaction that is the comparison of the actual situation against the expectations of the person. The aim of this research is to find out the life satisfaction levels of self-employed CPA's.

Method(s): This research utilized Life Satisfaction Scale introduced by Diener et al. (1982), and a personal data form developed by researchers. The questionnaire is created with the help of Google Forms, and sent to the chambers of CPA's all over Turkey that are enlisted on TURMOB's web site as of Feb. 3, 2018 to be shared with the members of the chambers. There are 77 chambers of CPA's, and eight chambers of Sworn-in CPA's.

Findings: The questionnaires are completed by 78 self-employed accountants. Initially, life satisfaction levels accountants', CPAs' and Sworn-in CPAs' are compared to their tenure in accounting profession, the number of dependant households they are obliged to look at, and their ages. Secondly with the help of independent sample t-test, life satisfaction levels of self-employed accountants are analyzed against their gender, marital status, and whether they chose their profession willingly or not. Data collected is analyzed with the help of IBM SPSS Statistics 20. Descriptive statistics are provided in detail. According to Pearson's Correlation Test there found no relationships between the scores of Life Satisfaction Scale and tenure as accountant, the number of households they are obliged to look at, and their ages. Additionally, independent sample t-test was performed to understand whether scores of Life Satisfaction Scale differed based on gender, marital status, and voluntary choice of profession. It is found out that scores of Life Satisfaction Scale only have statistically significant difference based on the voluntary choice of profession $(p<$ 0.05).

Conclusion: The average Life Satisfaction Scale score of self-employed accountants is 15.1154. This is to be interpreted as they are slightly satisfied with their lives. Considering the demographic factors, with 13.6897 the unhappiest respondents are those, who did not find a chance to choose their professions. The single CPAs follow with 13.8000 . With these scores, these two groups fall in the slightly dissatisfied segment. Female CPAs with 14.7059 are to be defined as neither satisfied not dissatisfied with their lives. As summarized in Table 2, male CPAs with 15.2295, and married CPAs with 15.3088, and self-ordained CPAs with 15.9592 compose the group who are slightly satisfied with their lives.

Both in a similar research and this research, female respondents make up around 20 percent of the sample. This displays that female CPAs belong to minority. Baştemur's research displays that among preconditions of happiness from life are being married, belonging to majority in the society, living in a democratic country, being able to make his/her own choices and having control of a person's own life. Baştemur's findings help us in explaining female CPAs neutral stance, and restricted freedom of individuals living in Turkish society blocking happiness.

Though limited with respondents of our questionnaire, CPAs believing that their lives are close to their ideals make 60 percent of the sample. The ratio of those thinking that the conditions of their lives are excellent is 58.21 percent. While those who state that they are satisfied with their lives make up 67.95 percent; respondents believing that, so far they have gotten the important things they want in life, make up 68.97 percent. Contrary to the acceptable levels of life satisfaction, the answers of respondents to the last question of the scale i.e. If I could live my life over, I would change almost nothing are challenging. The average of the scores of this question is 2.36 , that is 
47.18 percent. CPAs being somehow happy from their lives does not mean that they are not going to change anything in their lives if they could live their lives over.

Regarding the Turkish society, being composed of happy individuals means a lot. Happiness brings productivity, efficiency and effectiveness. This magical triangle would be the key of competitiveness of a country. So, academy, business world and chambers of professions are advised to co-operate, co-ordinate and coact in harmony to build courses of actions. 